Rina Kralj-Brassard*

Nella Lonza**

\title{
Rukopis Nikše Ragnine kao izvor podataka o proračunu Dubrovačke Republike u 16. stoljeću ${ }^{* * *}$
}

U radu se analizira sadržaj, utvrđuje datacija i autorstvo rukopisa R 3464 iz Zbirke rukopisa i starih knjiga Nacionalne i sveučilišne knjižnice u Zagrebu. Na temelju podataka o vrsti i visini državnih prihoda i rashoda Dubrovačke Republike zabilježenih u tom rukopisu određuje se razdoblje na koje se proračun odnosi. Vjerodostojnost strukture zapisa provjerava se usporedbom s vremenski najbližim pouzdanim podacima o državnim prihodima i rashodima s početka 17. stoljeća. Proračunski suficit pokazuje dobro stanje javnih financija Dubrovačke Republike u prvoj četvrtini 16. stoljeća, a struktura državnih prihoda potvrđuje izniman gospodarski položaj Dubrovnika. Premda obilježen mnogostrukim računskim pogreškama, koje upućuju na neobičan nemar prema brojčanim zapisima, Ragninin pregled proračuna, koji se donosi i transkribiran u prilogu, dragocjeno je svjedočanstvo o gospodarstvu Dubrovačke Republike početkom 16. stoljeća.

Ključne riječi: Nikša Ragnina, Dubrovnik, 16. stoljeće, državni proračun, suficit

\section{Opis i sadržaj rukopisa R 3464 iz Nacionalne i sveučilišne knjižnice u Zagrebu}

Tema ovoga rada zapis je o državnom proračunu iz rukopisa R 3464 iz Zbirke rukopisa i starih knjiga Nacionalne i sveučilišne knjižnice u Zagrebu. Kodeks nema izvorni naslov ni podatak o sastavljaču. Olovkom je na l. I dopisan naslov Indici delli publ. instrumenti di Ragusa; stara signatura Sveučilišne knjižnice je SM 30 B 16, a danas je signiran R 3464 i nosi naslov Notata diversa historiam civitatis Ragusinae illustrantia. ${ }^{1}$ Riječ je o složenom rukopisu raznolikoga sadržaja, u koji su prepisivale tri osobe, no glavninu je pisala jedna ruka. Rukopis je pisan na papiru i uvezan u karton, a

\footnotetext{
* Rina Kralj-Brassard, Zavod za povijesne znanosti HAZU u Dubrovniku, Lapadska obala 4, 20000 Dubrovnik, Republika Hrvatska, E-mail adresa: rinafran@gmail.com

** Nella Lonza, Zavod za povijesne znanosti HAZU u Dubrovniku, Lapadska obala 4, 20000 Dubrovnik, Republika Hrvatska, E-mail adresa: nella.lonza@gmail.com

*** Rad je nastao u sklopu projekta Tradicionalizam i inovacije u Dubrovniku od srednjeg vijeka do devetnaestog stoljeća (HRZZ IP-01-2018-5527). Zahvaljujemo dr. Ivanu Lupiću na korisnim primjedbama.

1 Novi naslov dao je Šime Jurić pri izradi kataloga rukopisa. Šime Jurić, Katalog rukopisa Nacionalne i sveučilišne biblioteke u Zagrebu, sv. I (Zagreb: Nacionalna i sveučilišna biblioteka, 1991), 204, pod br. 456. Za sumarni opis vidi: http://skupnikatalog.nsk.hr/Record/nsk.NSK01000676961/TOC\#toc.
} 
dimenzije su mu 30,6 $\times 20,5 \mathrm{~cm} .{ }^{2}$ Vjerojatno zbog prvotno nejasnoga i neodgovarajućega naslova preko sto godina nije privukao interes istraživača.

U Zbirku rukopisa i starih knjiga Nacionalne i sveučilišne knjižnice u Zagrebu rukopis je dospio iz knjižnice Velimira Gaja, što se vidi iz ex librisa „VGaj”, uz koji stoji 1873. godina (f. 6r). Spomenuti je vlasnik knjižnu zbirku 1871. preuzeo od oca Ljudevita. ${ }^{3} \mathrm{U}$ zbirci znamenitoga preporoditelja rukopis je bio već 1859., kad je iz njega prepisivao Ivan Kukuljević Sakcinski, izostavljajući ovaj dio o proračunu. ${ }^{4}$

No postoji trag o tome da se istim rukopisom (ili rukopisom istoga sadržaja) koristio još u 16. stoljeću Serafino Razzi pri pisanju svojega djela La Storia di Raugia jer uz sumarni pregled državnih prihoda navodi: „tutto si e ritratto dalle memorie fatte della sua citta, dal signor Niccolo di Ragnina..."5 Razzi je očito koristio i druge priloge iz toga rukopisa, npr. popis svih službi Dubrovačke Republike. ${ }^{6}$ Gelcich je, ne poznajući zagrebački rukopis, pretpostavio da je riječ o punom tekstu ljetopisa i da ga je autoru posudio Šimun Ragnina, koji je 1582. nakon očeve smrti naslijedio njegove knjige.

Prvi unos (f. 1r-2r) u rukopisu donosi pregled svih javnih službi dubrovačke države, gradskih i izvangradskih, pod naslovom Qui sono scripti tuti li officii et mag[istrati] dela cipta de Ragusa. ${ }^{8}$ Slijedi popis svih 47 dubrovačkih gradskih crkava s oznakama koje su župne (Qui sono scripte tute le gesie che sono in la cita de Ragusa et in quale sono le parochie, f. 2r-2v), svih 13 hospitala (Qui sono scripti tuti li ospetali in Raguxi, f. $3 v$ ) te popis relikvija u dubrovačkim crkvama (Qui sono scripti tuti li corpi sancti si dicono eser a Ragusa et in che gesia sono, f. 2v-3r). Sumarni pregled prihoda i rashoda Dubrovačke Republike, koji je predmet ovoga rada, upisan je na f. $4 \mathrm{r}-5 \mathrm{v}$ pod naslovom Qui pono tuta la intrata et inscita dela ilustre cipta de Ragusi tuto per ordine al anno. Nakon uobičajenoga prologa s citatima iz Konstantina Porfirogeneta i Epistola sv. Jeronima, donesenih u ponešto drukčijem poretku od uobičajenoga (f. 6r-7r), slijedi fragment Ragninina ljetopisa (Qui comenza la istoria de la edificatione de la cità di Rhagusa tuta per ordine, f. $7 \mathrm{v}-30 \mathrm{v}),{ }^{9} \mathrm{~s}$ time da se prijepis prve ruke prekida s krajem f. 25 r, usred upisa za godinu 843., a druga ruka nastavlja do zaključno 1001. godine

\footnotetext{
2 Jurić, Katalog rukopisa, ibid.

3 Pretpostavljamo da se na ovaj kodeks odnosi unos „Indice degli publici instrumenti della Republica di Ragusa. Cod. chart. saec. XVII. 4. Autogr. Ined. Lig. vet. H.III.1”. Velimir Gaj, Knjižnica Gajeva. Ogled bibliografskih studija (Zagreb: Tisak Narodne tiskare Gajeve, 1875), 189-190.

$4 \quad$ Kukuljević je prepisao samo prilog o knezovima umrlim u službi, nekoliko bilježaka iz prijepisa Zrcala i fragment Ragninine kronike. Njegov se prijepis čuva u Arhivu HAZU kao drugi dio rukopisa II.d.160.

5 Serafino Razzi, La Storia di Raugia (Lucca: per Venantio Busdraghi, [1595]), 179; Serafino Razzi, Povijest Dubrovnika, prev. Iva Grgić, Stjepan Krasić i Anamarija Paljetak (Dubrovnik: Matica hrvatska, Ogranak Dubrovnik, 2011), 201.

6 Usp. Razzi, La Storia di Raugia, 171-173; Razzi, Povijest Dubrovnika, 193-194.

7 Giuseppe Gelcich, „Prefazione”, u: Serafino Razzi, La Storia di Ragusa, prir. Giuseppe Gelcich (Ragusa: Editrice Tipografia Serbo-Ragusea A. Pasarić, 1903), XLVII-XLIX.

8 Popis je vjerojatno izrađen na temelju podataka o svakoj službi koji stoje u službenim svescima Zrcala.

9 Ti fragmenti odgovaraju str. 167-206 Nodilova izdanja.
} 
(f. 30v). Kao i u drugim rukopisima Ragninina ljetopisa, iza godine 743. umetnut je popis vlasteoskih obitelji (Qui sono scritte tutte le casate dali nobili di Ragusa, $\mathrm{f}$. $14 \mathrm{v}-17 \mathrm{v})$, s ponešto drukčijim podacima od onih iz rukopisa koje je poznavao Nodilo. Nakon praznoga f. 31, na f. 32r upisani su knezovi koji su umrli nakon izbora ili u vrijeme jednomjesečnoga mandata 1453. - 1524. (Rettori morti in palazzo et in chasa per avanti che entra in palazo), a od toga mjesta počinje i nova numeracija listova (f. $32 \mathrm{r}$ = f. 1r). Slijedi prijepis članova Velikoga vijeća iz Zrcala za razdoblje 1440. - 1500. (f. $1 v-13 r$ ). Pisala ga je prva ruka, što znači da pripada najstarijoj jezgri rukopisa. Listovi $13 \mathrm{v}-36 \mathrm{r}$ (numerirani suvremenom rukom) ostali su neispisani.

A tergo na f. 1r stoji prvom rukom prepisana nadgrobnica povodom smrti Marina Luccarija 1564. godine (inc. Mors non cuncta rapit), koju je možda sastavio sam Nikša Ragnina, pokojnikov ujak. ${ }^{10}$ Slijedi prijepis pjesme Ilije Crijevića sv. Vlahu Ad Blasius (!) pontificem protectorem (inc. Ragusa pater Blasi clientem); donosi neke varijante u odnosu na standardno izdanje. ${ }^{11} \mathrm{Na}$ f. 1v upisana je odluka Senata iz 1460-ih (godina nečitljiva zbog oštećenja) o izuzeću članova rodova Bona i Buchia kao kaznenih sudaca u postupcima protiv Miha Bone i Natalea (Boža) Buchia. Slijedi Zrcalo članova Velikoga vijeća i službi za 1549. - 1579. s upisima smrti do zaključno 1580. godine (f. 2r-11v). Na f. 11v-12r, još uvijek istom rukom, prepisana je pjesma Creazio mundi (inc. Nascentis coeli), nakon koje stoji zaziv zaštite sv. Vlaha. Slijedi nastavak Zrcala za 16. stoljeće, s tim što je samo do 1581. pisala prva ruka, a nastavak treća i četvrta ruka u 17. stoljeću (f. 12v-14r, 15r).

Najdulji dio ovoga složenog rukopisa zauzima fragment Ragninina ljetopisa. Natko Nodilo, koji je objavio njegov tekst, znao je za tri prijepisa. Najstariji se tada nalazio kod dum Luke Pavlovića u Dubrovniku, a Nodilo ga nije imao u rukama. ${ }^{12}$ Drugi prijepis, vjerojatno iz 18. stoljeća, koji je Kazali naknadno kolacionirao s Pavlovićevim, tada se čuvao u knjižnici zadarske gimnazije i, po svemu sudeći, izgorio je za vrijeme Drugoga svjetskog rata, ${ }^{13}$ a prijepis toga emendiranoga zadarskog rukopisa pohranjen je u Akademiji (danas Arhiv HAZU IV.c.22). ${ }^{14}$ U istoj instituciji čuva se i prijepis iz 1865. koji je Tommaso Burato izradio po Kukuljevićevoj narudžbi (I.c.55). Za posljednja je dva provjereno, a i za ostale se prema opisima čini da nisu imali priloge koje sadržava R 3464.

\footnotetext{
10 Za rodbinske odnose vidi: Nenad Vekarić, Vlastela grada Dubrovnika, sv. 6: Odabrane biografije (Pi - Z) (Zagreb; Dubrovnik: Zavod za povijesne znanosti HAZU u Dubrovniku, 2015), 96.

11 Usp. Ilija Crijević (Aelius Lampridius Cervinus, 1434 - 1520), De Epidauro et Ad Sanctum Blasium pro Rhacusa (1505), versio electronica (Ex libris), prir. Darko Novaković, Croatiae auctores Latini, pristup ostvaren 17. 4. 2020., http://www.ffzg.unizg.hr/klafil/croala/cgi-bin/getobject.pl?c.35:1:3.laud.

12 Speratus [Natko] Nodilo, [„Uvod”], u: Annales Ragusini anonymi item Nicolai de Ragnina, prir. Speratus Nodilo (Zagreb: JAZU, 1883), XI.

13 Neki su se autori nadali da je rukopisno blago te knjižnice odneseno u Italiju, no zasad nije pronađen nijedan njezin svezak, pa je ipak vjerojatnije da je stradalo u bombardiranju Zadra. Vidi: Pavao Galić, Povijest zadarskih knjižnica (Zagreb: Društvo bibliotekara Hrvatske, 1969), 38.

14 Nodilo, [„Uvod”], X-XI.
} 


\section{Autograf Nikše Ragnine?}

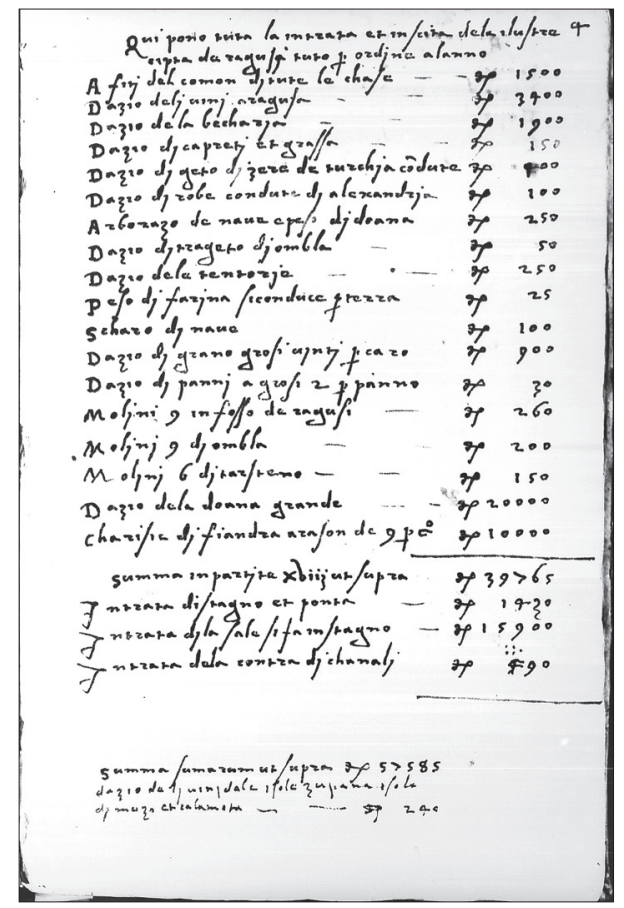

Zagrebački rukopis kompiliran je oko 1581. jer je tako datiran posljednji upis tergo, $\mathrm{f}$. 39r, a nakon 1579. prekidaju se i podaci iz Zrcala za 16. stoljeće (tergo, f. 11v). $\mathrm{U}$ isti je kodeks nastavila prepisivati druga ruka, nastavljajući ondje gdje je prethodna stala. Uvršteni dio Ragninina ljetopisa i činjenica da R 3464 prestaje sa 1581. upućuje u smjeru znamenitoga kroničara Nikole Ragnine, koji je umro godinu dana poslije, pa je potrebno ispitati može li se raditi o autografu.

Kao što je spomenuto, čini se da cjeloviti autograf Ragninina ljetopisa nije sačuvan. Bolja nije ni sudbina njegova prijepisa ljubavnih stihova Džore Držića, Šiška Menčetića i drugih dubrovačkih pjesnika, koji se do Drugoga svjetskog rata čuvao u knjižnici zadarske gimnazije. ${ }^{15}$ Pripremajući prvo kritičko izdanje, Vatroslav Jagić prepoznao je ruku koja je pisala i Lekcionar - što je potvrdio i Rački - te je za svezak ljubavne lirike uveo naziv Ranjinin zbornik, pod kojim je i danas poznat. ${ }^{16}$ Na rukopisu je pisalo „1507 adi 20 octubrio”, što znači da je Ragnina počeo s prijepisom još kao adolescent, no vjerojatno je unosio upise tijekom duljega vremena, ${ }^{17}$ kao što je bio slučaj i s njegovim Lekcionarom.

Nasreću, sačuvani su i neki Ragninini autografi. Ponajprije treba spomenuti rukopis Lekcionara, koji je od 17. do sredine 18. stoljeća pripadao obitelji Saraca, ${ }^{18}$ a preko Kukuljevićeve je knjižnice prije 1870. prispio u Arhiv HAZU u Zagrebu, gdje se i dan-

15 Rukopis se prethodno čuvao u Dubrovniku kod nasljednika Đanmarije Matteija, a u Zadar je dospio kao dar dr. Pulića, gimnazijskoga ravnatelja. Vatroslav Jagić, „Uvod”, u: Pjesme Šiška Menčetića Vlahovića i Gjore Držića, prir. Vatroslav Jagić (Zagreb: JAZU, 1870), XII-XIII.

16 O zborniku vidi: Nikola Batušić, Dunja Fališevac, ur., Zbornik Nikše Ranjine. O 500. obljetnici (1507. - 2007.) (Zagreb: HAZU, 2009).

17 Jagić je s ushitom komentirao: „Mi se klanjamo mladjahnu entusiazmu dubrovačkog vlasteoskog mladinca, što je mlade godine svoje u toli dičan posao uložio!” (Jagić, „Uvod”, XII-XIII). O problemu datacije detaljno vidi: Milan Rešetar, „Uvod”, u: Pjesme Šiška Menčetića i Gjore Držića i ostale pjesme Ranjinina zbornika, prir. Milan Rešetar, 2. izdanje (Zagreb: JAZU, 1937), XXVII-XLII.

18 Milan Rešetar, „Uvod” u: Zadarski i Ranjinin lekcionar, prir. Milan Rešetar (Zagreb: JAZU, 1894), X. Na f. 231r stoji ex libris Natalis de Saraca Anno Domini 1745. Rukopis je u ruke obitelji Saraca vjerojatno dospio u 17. stoljeću preko Nikšine unuke Jelene, njegova jedinoga izravnog potomka (vidi biografiju u: Vekarić, Vlastela grada Dubrovnika, 6, 96). 
as čuva (IV.a.32). ${ }^{19} \mathrm{U}$ taj je rukopis Ragnina počeo prepisivati još $1508 .,{ }^{20}$ a posljednji datirani upisi su iz 1577. godine. ${ }^{21}$ Sadržajem obuhvaća crkveni kalendar (ff. 1-10r) i lekcionar, tj. prijevod evanđelja i poslanica (ff. 13r-230r), a na listovima između Ragnina je upisivao podatke o rođenju djece i unuka (ime, dan i sat, kumove), počevši od rođenja kćeri Miruše 21. ožujka 1532. do rođenja unuka Nikše Šimunova 5. veljače 1577. godine (ff. 11v-12r). ${ }^{22}$ Naknadno je zbirci dodano kazalo (ff. Ir-XIv). Zbornik je popunjavan gotovo sedamdeset godina, pa nije čudno da se rukopis ponešto mijenja, no nema dvojbe da pripada istoj osobi. Zbog sukcesivno unošenih osobnih podataka o rođenju djece i unuka čini se da bi to morao biti Ragninin autograf.

Nadalje, u Državnom arhivu u Dubrovniku sačuvana su dva Ragninina vlastoručna pisma. Prvo je pisano 15. listopada 1529. nećaku Marinu Marinovu Luccari, pisaru na brodu S. Anton, ${ }^{23}$ a drugo 20. prosinca iste godine prijatelju Marinu Nikolinu Bujakoviću u Messinu. ${ }^{24}$ Bez obzira na to što nisu pisana s jednakom pomnjom kao knjižni rukopisi, nema dvojbe da je riječ o istoj ruci.

Na temelju spomenutih analiza može se utvrditi da je najstariji sloj rukopisa R 3464 autograf Nikole Ragnine. Nije jasan razlog zašto je u nj prepisao samo fragment vlastitih Anala, ni s kojim je ciljem prikupljao ostale podatke. U uvodu izdanja Lekcionara Rešetar je bio neobično strog u prosudbi Ragninina prepisivačkoga prinosa, ${ }^{25}$ ali zagrebački rukopis pokazuje da je takva ocjena nepravedna. Bez obzira na pogreške koje su mu se uvlačile u tekstove, upravo ta strast u prikupljanju i prepisivanju, koja ga nije napustila cijeloga života, sačuvala je neke vrijedne povijesne podatke, među kojima su i ovi o proračunu Dubrovačke Republike.

\section{Ragninin cursus honorum kao mogući izvor podataka o proračunu}

Otkud Ragnini podaci o prihodima i rashodima u državnom proračunu? S obzirom na većinom okrugle brojeve, svakako se radi o procjeni, a ne o realnim pokazateljima. No reklo bi se da je taj pregled sastavio netko tko je bio dobro upućen u osnovne financijske parametre dubrovačke države, kao i njezinu upravu. Je li to mogao biti sâm Nikola Ragnina?

19 Za detaljan opis i podatke o provenijenciji vidi: Jagić, „Uvod”, XIII; Rešetar, „Uvod”, u: Zadarski i Ranjinin lekcionar, IX-X.

20 Milan Rešetar, prir., Zadarski i Ranjinin lekcionar (Zagreb: JAZU, 1894), 99, 323: 1508 adi 20 octobrio in Ragusi Nicolo Marin de Ragnina aliter Nixa scrisi manu propria.

21 Rešetar, „Uvod”, u: Zadarski i Ranjinin lekcionar, IX.

22 Podaci su prikazani i obrađeni u: Vedran Stojanović, Nella Lonza, „Krsna kumstva u Dubrovniku 18. stoljeća: djeca, roditelji i kumovi kao čvorovi društvenih mreža", Anali Zavoda za povijesne znanosti HAZU u Dubrovniku 54/2 (2016): 297-298.

23 Hrvatska - Državni arhiv u Dubrovniku (dalje: DADU) - Miscellanea saeculi XVI, ser. 76, kut. 9, sv. $3 / 1$, br. 67 .

24 Miscellanea saeculi XVI, kut. 9, br. 68 .

25 „Već nam to svjedoči da Ranjina nije bio čovjek velika uma, a kad se malo pregledaju njegovi prijepisi i njihove bezbrojne i grdne svakojake griješke i bezmislice, tada nam se on prikazuje kao čovjek baš plitka uma.” Rešetar, „Uvod”, u: Zadarski i Ranjinin lekcionar, XV-XVI. 
Nikola Marinov Ragnina primljen je u Veliko vijeće 1514. godine. ${ }^{26}$ Kao i drugi plemići, u ranim godinama biran je na službe po utvrdama. ${ }^{27}$ Godine 1532. bio je izabran za nadglednika soli (salinaro), 1533. za nadzornika javnih radova (officiale lavoreri de scritta), 1534. za općinskoga procjenitelja (stimatore), 1536. za nadzornika fontika (fondechero), 1537., 1548. i 1559. za tržnoga nadzornika (justitiere), a 1543. i 1545. za nadzornika općinske žitnice (massaro de le biave del comun). ${ }^{28} \mathrm{Na}$ neugodnu službu zdravstvenoga nadzornika (cazamorto) izabran je 1545. godine. Često je bio biran u prizivno vijeće (Collegio dele appelatione). ${ }^{29}$ Više je puta bio knez na Lopudu (1536., 1543., 1550., 1556., 1563., 1566., 1570.), a po jednom knez Šipana (1531.) i Slanske knežije (1547.). ${ }^{30}$ Od 1565. do 1579. četiri je puta biran za dubrovačkoga kneza. ${ }^{31}$ Član Maloga vijeća bio je 1574. i 1580., 32 a u redovima Senata 1572., 1577., 1578., 1579. i 1582. godine. ${ }^{33}$ Dakle, na službama u državnom aparatu Ragnina je stekao znatno iskustvo i bio je u prilici steći uvid u ekonomsku stranu njegova funkcioniranja.

No koliko je Ragnina bio u prilici upoznati državne financije s njihove konkretne, praktične strane? Još od srednjega vijeka u Dubrovniku, kao i u dalmatinskim gradovima, postojala je služba državnih blagajnika (camerarii, camerlengi), koji su primali sve općinske prihode od onih koji su ih ubirali i obavljali sve isplate na temelju naredbi ovlaštenih institucija. ${ }^{34}$ Njihova je služba, uključujući način vođenja knjiga, detaljno regulirana 1453., kad je zbog obujma posla trojici blagajnika pridružen četvrti. ${ }^{35}$ Još prema staroj statutarnoj odredbi, vjerojatno iz 1278., početkom svakoga mjeseca bili su dužni podnositi račune knezu i Malom vijeću. ${ }^{36}$ Međutim, 1408. uvedena je nova služba petorice državnih računovođa (officiales rationum, ufficiali delle ragioni), koja je pregledavala račune i nadzirala svako raspolaganje državnim novce-

\footnotetext{
26 DADU, ser. 21.1, sv. 2 Specchio del Maggior Consiglio dell'anno 1500 (dalje: Specchio), f. 383v. Za ostale biografske podatke i osnovnu literaturu o Ragnini vidi: Vekarić, Vlastela grada Dubrovnika, 6, 96-98.

27 Specchio, f. $319 \mathrm{v}, 329 \mathrm{v}$.

28 Specchio, f. 132r, 137v, 147r, 154r, 205v, 223v.

29 Specchio, f. 181r, 187r, 189r, 190v-191r, 192r.

30 Specchio, f. 282v, 286v, 292r-293r.

31 Vekarić, Vlastela grada Dubrovnika, 6, 96.

32 Specchio, f. 19r, 29v.

33 Specchio, f. 74v, 75v-77r. Nepotpuno uočeni podaci naveli su Gelcicha na sumnju da Ragnina nije uživao puno povjerenje dubrovačkih vlasti, što se može odbaciti (usp. Gelcich, „Prefazione”, XLVIII).

34 Taj je sustav ukratko opisan u: Filip de Diversis, Opis slavnoga grada Dubrovnika, predgovor, transkripcija i prijevod s latinskoga Zdenka Janeković Römer (Zagreb: Dom i svijet, 2004), 75-76 163-164; Giacomo di Pietro Luccari, Copioso ristretto de gli annali di Rausa (In Venetia: Antonio Leonardi, 1605), 169. O istovjetnim službama općinskoga blagajnika u nekim dalmatinskim gradovima i njihovim sačuvanim knjigama vidi: Serđo Dokoza, „Računski spisi srednjovjekovne korčulanske komune", Povijesni prilozi 20 (2001), br. 20: 155-160.

35 Branislav Nedeljković, prir., Liber viridis (Beograd: SANU, 1984), cap. 439, str. 383-386.

36 Dubrovački statut, VIII, 28. Statut grada Dubrovnika, prir. i prev. Ante Šoljić, Zdravko Šundrica i Ivo Veselić (Dubrovnik: Državni arhiv u Dubrovniku, 2002), 433. Prema odredbi iz 1358., račun se polaže knezu (Nedeljković, Liber viridis, cap. 6).
} 
$\mathrm{m},{ }^{37}$ od 1415. i ono državnih blagajnika. ${ }^{38}$ Obje službe u srcu državnoga financijskog poslovanja bile su neprofesionalne i na njih su na određeni rok birani dubrovački plemići nešto zrelije dobi. ${ }^{39}$ No među njima se nije našao Nikša Ragnina. Zaobišle su ga najviše financijske službe na kojima bi mogao ne samo pratiti tijek novca nego i doslovce držati u rukama glavne državne računske knjige i nadzirati upise dugovanja i tražbina državne blagajne.

Stoga je detaljan pregled državnih prihoda i rashoda „iz prve ruke” Ragnina mogao imati tek u poznijoj dobi, nakon 1565., kad je biran za kneza, za člana Senata ili Maloga vijeća. No moguće je i da je taj pregled od nekoga dobio jer u njegovu strast za prikupljanjem podataka ne treba dvojiti.

Nikša Ragnina, čini se, nije imao dara za baratanje brojevima, ili za njih nije previše mario. Nije uočio, niti ispravio, mnoge, i to krupne pogreške u zbrajanju. ${ }^{40}$ Dva sačuvana pisma pokazuju da se Ragnina bavio trgovinom. ${ }^{41} \mathrm{Da}$ je kojim slučajem sa sličnim nemarom prema brojevima vodio svoje trgovačke knjige - a sigurno je imao barem uobičajene rudimentarne popise prihoda i rashoda, dugova i dužnika ${ }^{42}-$ bili bi to teški propusti koji bi se mogli odraziti na poslovanje. Neke su nepodudarnosti možda uzrokovane time što je Ragnina podatke dodavao, sudeći prema rukopisu, možda i znatno kasnije, u starijoj životnoj dobi. Serafino Razzi, koji je preuzeo samo osnovne stavke ovoga proračuna, ispravio je pogreške u zbrajanju ili se, možda, služio prijepisom u kojem je to već bilo učinjeno. ${ }^{43}$ Mane ovoga zapisa proračuna Dubrovačke Republike ipak ne poništavaju povijesnu vrijednost ovoga izvora kao zasad najstarijega poznatoga sumarnog pregleda financija dubrovačke države.

\section{Datacija podataka}

Vremenski okvir izvornoga zapisa o proračunu vezan je uz pitanje je li Ragnina pregled budžeta sam sastavio ili ga je prepisao iz nekoga izvora koji mu se našao pod

\footnotetext{
37 Nedeljković, Liber viridis, cap. 123, str. 87-91.

38 Nedeljković, Liber viridis, cap. 149, str. 105-106. Prvu knjigu koju su vodili (DADU, Officiales rationum, ser. 18, sv. 2) predstavio je i djelomično obradio Mihailo Dinić, „Jedna dubrovačka arhivska knjiga petnaestog veka", Istorijski časopis 12-13 (1961-1962): 15-29. U uputama novim dužnosnicima najprije se naglašava da moraju znati koji se računi bilježe i na kojem se mjestu evidentira dugovanje ili tražbina. Vidi: DADU, Officiales rationum, ser. 18, sv. 1 - Istruzioni per l'Uffizio delle Cinque Ragioni, f. 58-59. U tehničkoj strani posla pomagao im je posebni pisar-računovođa (rationatus, raxonato) (Diversis, Opis slavnoga grada Dubrovnika, 78, 165; Nedeljković, Liber viridis, cap. 360 bis).

39 Prema odredbama iz 1445., blagajnici su se birali na godinu dana među plemićima koji su navršili trideset godina (Nedeljković, Liber viridis, cap. 360 bis, str. 318).

40 Naprimjer, zbroj prihoda iz Konavala je netočan. Zbroj 360 (davanja za promet vinom), 80 (davanja za promet mesom) i 150 (prihod od najma četrnaest mlinova) za Ragninu je 490 umjesto 590 (HR Nacionalna i sveučilišna knjižnica u Zagrebu /dalje: NSK/ - Zbirka rukopisa i starih knjiga, R 3464, f. $4 \mathrm{v})$.

$41 \quad$ Miscellanea saeculi XVI, kut. 9, sv. 3/1, br. 67 i 68.

42 Niz poslovnih knjiga iz 15. i 16. stoljeća čuva se u: DADU, Privata, ser. 19.

43 Razzi, La Storia di Raugia, 178-179; Razzi, Povijest Dubrovnika, 200.
} 
rukom. Na koje se vrijeme odnose prihodi i rashodi? Je li proračun uopće iz vremena Nikše Ragnine?

Još je Serafino Razzi u knjizi objavljenoj nedugo nakon Ragninine smrti istaknuo zastarjelost ovih podataka. Kao prvi argument iznio je da Dubrovačka Republika već dulje vrijeme ne uživa prihode od trgovine tkaninama iz Flandrije. ${ }^{44}$ Razzi je imao i druge primjedbe na proračun, a na temelju vojnih troškova, za koje je utvrdio da su zbog izvanrednih okolnosti prikazani u previsokom iznosu, okvirno ga je smjestio u sedmo desetljeće 16 . stoljeća. ${ }^{45} \mathrm{Na}$ temelju procjene plaće i broja vojnika može se zaključiti da vojni troškovi ipak nisu iznimno visoki i da, čini se, ne odgovaraju pojačanom angažiranju vojne sile u kriznim vremenima. ${ }^{46}$ Drugi podaci o troškovima pokazat će da je ta Razzijeva procjena bila pogrešna. Da Razzi nije poznavao sve pojedinosti o tijekovima državnoga novca i izvorima za pokrivanje pojedinih državnih rashoda pokazuje primjedba o troškovima boravka propovjednika u Dubrovniku. Razzi smatra da je pisac proračuna te troškove izostavio, a bili su znatni, oko 300 dukata godišnje. ${ }^{47}$ Međutim, troškovi propovjednika redovito su isplaćivani u okviru troškova kneza i kneževa dvora sigurno i u Razzijevo vrijeme jer je tako zabilježeno u svesku troškovnika Dvora iz sedamdesetih godina 16. stoljeća. ${ }^{48}$ Pisac proračuna to je nesumnjivo znao, pa ih nije zasebno prikazivao, a Razziju takve detalje o državnim troškovima nitko nije priopćio.

Spomen prihoda od najma devet mlinova u prokopu uz zapadne gradske zidine smješta vremenski okvir proračuna na razdoblje nakon izgradnje vodovoda 1440. godine.

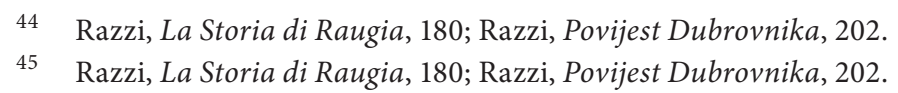

46 Broj bombardiera u proračunu i njihova prosječna mjesečna plaća od oko 3 i pol dukata odgovara poznatim podacima o tim specijaliziranim vojnicima obrtnicima. Vidi: Domagoj Madunić, „The Defensive System of the Ragusan Republic (c. 1580-1620)", u: The European Tributary States of the Ottoman Empire in the Sixteenth and Seventeenth Centuries, ur. Gábor Kármán i Lovro Kunčević (Leiden: Brill Publishing, 2013), 353. Na popisu bombardiera na plaći u svibnju 1559. godine je 21 osoba, uglavnom stranci. Plaće su iznosile od 1 dukata i 32 groša do 4 dukata (DADU, Detta, ser. 6, sv. 2, f. 14v15). Broj vojnika na utvrdi Sokol u proračunu okvirno odgovara stanju 1463. godine, kad je posadu s kapelanom činilo 17 osoba. U kriznim vremenima ta je posada mogla narasti i na 40 ljudi. Vidi: Niko Kapetanić, Sokol grad u Konavlima (Dubrovnik: Vlastita naklada, 2013), 37, 39. Primijeni li se kao mjera za procjenu broja vojnoga osoblja jedinična mjesečna plaća vojnika na tvrđavi Sokol u Konavlima, kojih je bilo 15, a plaćeni su 340 dukata godišnje, na temelju ukupnoga iznosa isplaćenog soldatima i barabantima dođe se do broja od oko 290 osoba. Toliki broj vojnoga osoblja, čak i ako se među drugim stavkama krije još vojnih troškova, nije prevelik, posebno ako se uzme u obzir da su barabanti, kao profesionalni vojnici, plaćeni više od običnih soldata. U 16. stoljeću Dubrovnik je u redovnim prilikama angažirao od 100 do 130 barabanata. Vidi: Trpimir Macan, „Dubrovački barabanti u XVI stoljeću”, Anali Historijskog instituta JAZU u Dubrovniku 8-9 (1960-1961): 305. Vojna sila Dubrovačke Republike rijetko je prelazila 350 ljudi, ali se zato u izvanrednim situacijama mogla pojačati s više stotina vojnika (Madunić, „The Defensive System of the Ragusan Republic /c. 1580-1620/”, 348, 351).

47 Razzi, La Storia di Raugia, 179; Razzi, Povijest Dubrovnika, 201.

48 Rina Kralj-Brassard, „Detta presvijetlog i preuzvišenog gospodina kneza: troškovi Dvora u Dubrovniku od 16. do 19. stoljeća", Anali Zavoda za povijesne znanosti HAZU u Dubrovniku 52/1 (2014): 137. 
Prihod od lučke pristojbe (arborazo) upućuje na razdoblje prije 1485. ili nakon 1507. kao moguće vrijeme na koje se proračun odnosi jer je plaćanje arboratika bilo ukinuto između 1485. i 1507. kao poticajna mjera za oporavak brodarstva. ${ }^{49}$

No, korisniji su podaci o trgovini s Engleskom. Po proračunu iz R 3464, davanja od 9\% na vrijednost uvoza odnosno tranzita kariseja, engleske tkanine koja je u Dubrovnik dolazila preko Flandrije, donosila su u državnu blagajnu oko 10.000 dukata godišnje, blizu šestine proračuna. Bio je to treći državni prihod po veličini nakon onoga od carinarnice i prodaje stonske soli. Iz podatka o iznosu davanja može se okvirno procijeniti vrijednost tranzitne trgovine engleskim vunenim tkaninama preko Dubrovnika na više od 110.000 dukata godišnje.

Cijena kariseja, engleske tanje vunene tkanine, koja je najsličnija suvremenoj tkanini za izradu muških odijela, ovisila je o stupnju obrade. Karisej se motao u bale, koje su se dodatno štitile od vlage štavljenim goveđim kožama. ${ }^{50}$ Početak unosne dubrovačke trgovine kvalitetnim engleskim vunenim tkaninama seže u sredinu 15 . stoljeća. Dubrovčani su započeli s izvozom engleskoga tekstila preko svoje luke, i to najprije koristeći brodski prostor na mletačkim državnim galijama. Te su državne galije plovile u konvojima. ${ }^{51}$ Flandrijski konvoj (muda) kretao je krajem proljeća iz Venecije i do engleske luke Southampton stizao za tri do šest mjeseci. U povratku je doticao flandrijske luke na europskom kopnu. Cijelo putovanje s usputnim zaustavljanjima trajalo je i do dvije godine. Na to putovanje, koje je povezivalo najvažnije sjevernoeuropske luke s Venecijom, odlazile su najbolje i najčvršće galije. ${ }^{52}$ Krajem 15. stoljeća do Engleske su plovili i dubrovački brodovi. ${ }^{53}$ Iz Southamptona, koji je bio glavna engleska izvozna luka za robu stranih trgovaca, put je, uz usputna zaustavljanja, vodio u Dubrovnik, a odatle u osmanska trgovačka središta Aleksandriju, Jedrene i Smederevo. ${ }^{54}$

Prihod od 10.000 dukata od izvozne odnosno tranzitne trgovine karisejom, koji donosi Ragnina, nipošto nije nerealan. Dubrovačka trgovina s Engleskom doživjela je vrhunac u drugom desetljeću 16. stoljeća, kad se Dubrovčani javljaju u dvostrukoj ulozi trgovaca i ulagača. ${ }^{55}$ Širenje poslovanja s trgovine tkaninama (i drugom robom) na bankarstvo prirodan je tijek razvoja privredne djelatnosti. Uvozno-izvozni poslovi praćeni povremenim viškovima ili manjkovima gotovine zahtijevali su dostupnost

49 Niz odluka o arboratiku zabilježen je u uputama za službenike Računskoga ureda (Istruzioni per l'Uffizio delle Cinque Ragioni, sv. 1, f. 60-61).

50 Veselin Kostić, Dubrovnik i Engleska 1300-1650 (Beograd: SANU, 1975), 126, 191, 193.

51 Kostić, Dubrovnik i Engleska 1300-1650, 105.

52 Bernard Doumerc, „Il dominio del mare”, u: Storia di Venezia. Dalle origini alla caduta della Serenissima, IV: Il Rinascimento. Politica e cultura, ur. Alberto Tenenti i Ugo Tucci (Roma: Enciclopedia Italiana, 1996), pristup ostvaren 8. 4. 2020., http://www.treccani.it/enciclopedia/il-rinascimento-politica-e-cultura-tra-pace-e-guerra-le-forme-del-potere-il-dominio-del-mare_\%28Storia-di-Venezia\%29/.

53 Kostić, Dubrovnik i Engleska 1300-1650, 107.

54 Kostić, Dubrovnik i Engleska 1300-1650, 111.

55 Kostić, Dubrovnik i Engleska 1300-1650, 111, 113. 
odgovarajućih sredstava plaćanja na udaljenim mjestima i stvarali potrebu za mjenjačnicama, transferom novca i kreditima. ${ }^{56}$

Koliko je bila unosna izvozna trgovina engleskom vunenom tkaninom svjedoče podaci o visokoj zaradi jednoga dubrovačkoga trgovačkog društva. S uloženim kapitalom od 7.300 dukata u tri godine poslovanja od 1537. do 1540. zabilježilo je neto dobitak od 5.000 dukata. ${ }^{57}$ Razumljivo je da se uz tako visoke prinose dubrovački kapital povlačio iz domaće proizvodnje sukna, što je, uz nesmiljenu konkurenciju kvalitetnije uvozne robe, bio jedan od uzroka propasti domaće manufakture vunenih tkanina. ${ }^{58}$ Dubrovnik je, po svoj prilici, dominirao u posredničkoj trgovini kvalitetnim tkaninama između Engleske i Levanta. ${ }^{59}$ Visoki iznos prihoda od kariseja smješta Ragninin proračun najranije u drugu polovinu 15. ili, vjerojatnije, u prva desetljeća 16 . stoljeća. Dva državna rashoda spomenuta u proračunu omogućuju još nešto preciznije određenje vremena na koje se odnose Ragninine brojke. ${ }^{60} \mathrm{U}$ popisu rashoda ističu se dva tributa. Prvi je onaj koji se plaćao ugarskom kralju, i to 500 dukata. Gornja vremenska granica plaćanja toga tributa je 1526. godina. ${ }^{61}$ Dubrovački državni rashod je i tribut osmanskom vladaru, koji je ujedno najveća pojedinačna rashodovna stavka, od 12.500 dukata. Toliki se iznos harača plaćao od 1481. godine. ${ }^{62}$

Uzimajući u obzir državne prihode od mlinova u predgrađu uz zapadne zidine, od lučkih pristojbi, od nameta na trgovinu tkaninama te rashode za tribute osmanskom i ugarskom vladaru, vremenski okvir proračuna koji je zabilježio Ragnina sužen je na dva moguća intervala: između 1481. i 1485. ili između 1507. i 1526. godine. Oba su izvan razdoblja za koja je Ragnina mogao imati izravni uvid u podatke o proračunu. Za prvoga intervala na koji bi se proračun mogao odnositi Ragnina se još nije bio rodio, a za drugoga je bio premlad za obnašanje dužnosti koje bi mu omogućavale uvid u sve sastavnice proračuna Dubrovačke Republike.

Prvi interval razdoblje je neposredno nakon što je smrću sultana Mehmeda II. Osvajača zaustavljen rast harača zbog kojega je Veliko vijeće donijelo odluku o raspisivanju javnoga zajma za pokrivanje toga nabujaloga državnog troška. Zajam su trebali upisati svi vlasnici nekretnina i pokretne imovine. Planirane su i druge mjere štedn-

\footnotetext{
56 Richard A. Goldthwaite, The Economy of Renaissance Florence (Baltimore: The Johns Hopkins University Press, 2009), 203-205.

57 Kostić, Dubrovnik i Engleska 1300-1650, 198.

58 Ignacij Voje, „Poskusi kvantifikacije trgovskega prometa in proizvodnje v srednjeveškem Dubrovniku”, Zgodovinski časopis 42 (1988), br. 3: 385.

59 Kostić, Dubrovnik i Engleska 1300-1650, 199.

60 Provjera iznosa prihoda od nekretnina, podaci o proizvodnji soli i broju mlinova u dubrovačkom predgrađu, na Ombli, u Trstenu i Konavlima ili troškovi Kneževa dvora nisu se pokazali dobrim pistama za pobliže određivanje vremenskoga okvira proračuna.

61 Za pojedinosti o diplomatskim naporima koji su doveli do prestanka plaćanja tributa hrvatsko-ugarskim kraljevima vidi: Vinko Foretić, Povijest Dubrovnika do 1808., knj. 2 (Zagreb: Nakladni zavod Matice hrvatske, 1980), 8-35.

62 Vesna Miović, Dubrovačka diplomacija u Istambulu (Zagreb; Dubrovnik: Zavod za povijesne znanosti HAZU u Dubrovniku, 2003), 14.
} 
je. ${ }^{63}$ Ozbiljno se razmišljalo o zadiranju u obiteljske prihode, što je vrlo nepopularna mjera s potencijalom za masovni otpor, pa se čini malo vjerojatnim da bi se suficitarni državni proračun odnosio na razdoblje neposredno nakon te krize. S obzirom na važnost prihoda od tranzitne trgovine karisejom, vjerojatnije je da Ragnina barata podacima o prihodima i rashodima između 1507. i 1526. godine. Podaci o prihodima i rashodima Dubrovačke Republike došli su do Ragnine, po svoj prilici, s određenim vremenskim odmakom, kao stariji, no jesu li vjerodostojni? Raščlamba proračuna upućuje na sustavan i pouzdan izvor iz kojih su preuzeti. Najprije su zabilježeni državni prihodi, i to po vrsti prihoda i teritorijalnom ključu jer su izdvojeni prihodi iz Stona i Pelješca, iz Konavala te s otoka Šipana, Lopuda i Koločepa.

Mogućnosti provjere vjerodostojnosti zapisa o proračunu zasad su dosta ograničene. Studije o stanju javnih financija drugih istočnojadranskih komuna odnose se okvirno na razdoblje od 13. do 15. stoljeća, što onemogućuje usporedbu s dubrovačkim proračunom iz znatno kasnijega razdoblja. ${ }^{64}$ Slična su ograničenja pokušaju li se iznosi iz zapisa Nikše Ragnine usporediti s unosima u državnim knjigama s detaljnim upisima svih prihoda i rashoda. Najstarija knjiga državne blagajne, koja čuva zapise iz 1535./1536., nije dosad istražena, ${ }^{65}$ vjerojatno zbog svoje zahtjevnosti. U njoj sadržani podaci nesumnjivo će baciti svjetlo i na Ragninine navode jer su podaci iz nje mlađi samo desetljeće ili dva od onih iz Ragnininih zapisa.

Vremenski najbliži uzorak pouzdanoga i cjelovitoga državnog proračuna (bilance) Dubrovačke Republike sačuvan je iz drugoga desetljeća 17. stoljeća, cijelo stoljeće nakon Ragninina proračuna. Precizna bilanca državnih prihoda i rashoda rađena je svrhovito, kao podloga za provođenje mjera štednje. ${ }^{6}$ Iznosi prihoda i rashoda dvaju državnih proračuna, onoga iz 16. i onoga iz 17. stoljeća, nisu neposredno usporedivi. Zbog potrebe usklađivanja prihoda i rashoda, posebno rezanjem pojedinih rashodovnih stavki, raščlamba prihoda i rashoda očekivano je mnogo detaljnija u vrlo preglednom deficitarnom proračunu za razdoblje od 1610. do 1619. godine. Najkrupni-

63 Zdravko Šundrica, „Kako su stari Dubrovčani rješavali financijske krize”, u: Zdravko Šundrica, Tajna kutija Dubrovačkog arhiva, II (Zagreb; Dubrovnik: Zavod za povijesne znanosti HAZU u Dubrovniku, 2009), 330-332.

64 Za iscrpnu studiju gospodarskoga razvoja Korčule u srednjem vijeku vidi: Serđo Dokoza, Dinamika otočnog prostora. Društvena i gospodarska povijest Korčule u razvijenom srednjem vijeku (Split: Književni krug Split, 2009). Preciznu bilancu splitske komune obradio je Grga Novak. Tako su se prihodi splitske komune od 1345. do 1346. sastojali od izvozne i uvozne carine (comercium), daća na meso, ribu (datium), globe i primitaka od komunalnih zemalja na Šolti i Čiovu, mlinova, pristaništa, brodarice. Redovni rashodi uključivali su plaće potestatu, liječniku fiziku i kirurgu, kancelarijske potrebe, održavanje luke i bedema. Splitska komuna ostvarivala je suficit. Vidi: Grga Novak, Povijest Splita, knj. I: Od prethistorijskih vremena do definitivnog gubitka pune autonomije 1420. god. (Split: Matica hrvatska, Pododbor, 1957), 454-455, 462-463. Za pregled razvoja srednjovjekovnoga gospodarstva na jadranskom prostoru vidi: Tomislav Raukar, „Prilog poznavanju sistema prihoda dalmatinskih gradova u XIV. stoljeću", Historijski zbornik 21-22 (1968-1969): 343-370; Tomislav Raukar, Srednjovjekovne ekonomije i hrvatska društva (Zagreb: Filozofski fakultet Sveučilišta u Zagrebu, 2003).

65 DADU, Cassa communis, ser. 59, sv. 1.

66 DADU, Tesorieri Bilancia 1610-1619, ser. 49, sv. 1. Tu bilancu analizirao je Antonio Di Vittorio, Finanze e moneta a Ragusa nell'età delle crisi (Napoli: Giannini, 1983). 
ja razlika između stavki dvaju proračuna izostanak je prihoda od trgovine karisejom. Mnoge se stavke ipak sadržajno poklapaju ${ }^{67}$ Stoga se može zaključiti da je Ragninin proračun, doduše sa svim spomenutim manama, prijepis iz nekoga pouzdanog izvora.

Prema Ragnininu proračunu, gotovo 80\% ukupnih prihoda Dubrovačke Republike početkom 16. stoljeća dolazilo je iz tri izvora: od carinarnice oko 20.000 dukata, od prodaje stonske soli 15.900 dukata i od trgovine karisejom 10.000 dukata. Četvrti po važnosti prihod je od daća na prodaju vina, s nešto malo manje od $10 \%$ ukupnih prihoda, zatim daća na prodaju mesa od oko $4 \%$ ukupnih prihoda, slijedi prihod od nekretnina, najviše od najma kuća, od 1.500 dukata. Više je različitih daća u manjim iznosima, među kojima se po iznosu ističe prihod od daće na žito u iznosu od 900 dukata.

Rashodi Dubrovačke Republike mogu se ugrubo podijeliti na dva dijela. Prvi, manji dio, oko $40 \%$ ukupnih rashoda, odnosi se na troškove dvora kneza, plaće dužnosnicima i službenicima u upravi, učiteljima i liječnicima, plaće vojnom osoblju i radnicima u gradu i u distriktu. Drugi, veći dio, oko 60\%, uključuje tribute, posebno tribut osmanskom vladaru i popratne troškove, različite darove osmanskim velikodostojnicima, njihovo uzdržavanje kada dolaze u grad, darove drugim strancima i namete na sol koji se isplaćuju Osmanskom Carstvu. Veći dio rashoda cijena su iznimnoga trgovinskog položaja Dubrovčana prema Osmanskom Carstvu. Bez plaćanja tributa Dubrovčani ne bi imali pristup osmanskom tržištu uz preferencijalne uvjete. Odatle dolazi zarada najprije za državu - jer su tri najvažnija državna prihoda u proračunu iz 16. stoljeća, carinarnica, prodaja stonske soli i trgovina karisejom, izravna posljedica plaćanja tributa osmanskom vladaru - a još više izvor dobiti za pojedince uključene u trgovinu na velikim prostorima toga carstva.

U prikazu rashoda Dubrovačke Republike dijelom je primijenjen teritorijalni ključ. Zasebno su prikazani troškovi koji se odnose na Ston i na Konavle. Tako su izdvojeni troškovi potknezova i plaće vojnika u utvrdi Sokol u Konavlima. Ti državni troškovi niži su od prihoda koji se ostvaruju s konavoskoga područja od nameta na prodaju vina, mesa i od najma mlinova. Suficit se, čini se, ostvarivao i na mikrorazini. Teritorijalna podjela rashoda ne prati istovrsnu podjelu prihoda. Prihod od prodaje vina s Elafitskih otoka prikazan je zasebno, a državni rashodi koji se odnose na upravu tih otoka nisu izdvojeni. ${ }^{68}$

Završno se može istaknuti da je Ragninin proračun dragocjeno svjedočanstvo „zdravlja” državnih financija Dubrovačke Republike u prvoj četvrtini 16. stoljeća. Državni proračun bio je suficitaran $\mathrm{s}$ viškom prihoda nad rashodima od oko 20.000 dukata. ${ }^{69}$ Okvirno, prihodi su gotovo za četvrtinu nadmašivali rashode.

\footnotetext{
67 Tesorieri Bilancia 1610-1619, sv. 1, f. [38-42].

68 R 3464, f. 4, 5.

69 R 3464, f. 4v.
} 


\section{Zaključak}

Najstariji sloj rukopisa R 3464 Sveučilišne knjižnice u Zagrebu autograf je poznatoga kroničara i prepisivača Nikole (Nikše) Ragnine. Među ostalim zapisima donosi i procjene osnovnih stavki državnoga proračuna, koji dosad nije bio zamijećen niti korišten u literaturi. Na temelju podataka o vrsti i visini državnih prihoda i rashoda Dubrovačke Republike može se zaključiti da se odnosi na razdoblje između 1507. i 1526. godine. U tom periodu Nikša Ragnina nije mogao imati detaljan uvid u stanje državnih financija jer su mu zbog mladosti izmicale ključne državne službe. Ragnina je podatke o državnim prihodima i rashodima primio s vremenskim odmakom, preuzevši ih iz nekoga nama nepoznatog izvora. Zapisi o prihodima i rashodima obilježeni su višestrukim pogreškama u zbrajanju, no sadržajno se čine vjerodostojnima, što se može zaključiti usporedbom s vremenski najbližim poznatim proračunom Dubrovačke Republike (bilancom) s početka 17. stoljeća. Prenoseći podatke iz prve četvrtine 16. stoljeća, Ragninin autograf dragocjeno je svjedočanstvo o izvrsnom stanju državnoga proračuna, koji je u to vrijeme ostvarivao znatan suficit. 


\section{Prilog}

Pregled proračuna Dubrovačke Republike, NSK, R 346470

[f. 4]

Qui pono tuta la intrata et inscita dela ilustre cipta de ragusi tuto per ordine al anno

\begin{tabular}{|c|c|c|}
\hline Afiti del comon di tute le chase & ducati & 1500 \\
\hline Dazio deli uini a ragusa & & 3400 \\
\hline Dazio dela becharia & & 1900 \\
\hline Dazio di capreti et grassa & & 150 \\
\hline Dazio di geto di zere de turchia condute & & 400 \\
\hline Dazio di robe condute di alexandria & & 100 \\
\hline Arborazo de naue e peso di doana & & 250 \\
\hline Dazio di trageto di ombla & & 50 \\
\hline Dazio dele tentorie & & 250 \\
\hline Peso di farina si conduce per terra & & 25 \\
\hline Scharo di naue & & 100 \\
\hline Dazio di grano grosi uinti per caro & & 900 \\
\hline Dazio di panni a grosi 2 per panno & & 30 \\
\hline Molini 9 in fosso de ragusi & & 260 \\
\hline Molini 9 di ombla & & 200 \\
\hline Molini 6 di tarsteno & & 150 \\
\hline Dazio dela doana grande & & 20000 \\
\hline Charisia di fiandra a rason de 9 per cento & & 10000 \\
\hline summa in partite XVIII ut supra & & 39765 \\
\hline Intrata di stagno et ponta & & 1430 \\
\hline Intrata dila sale si fa in stagno & & 15900 \\
\hline Intrata dela contra di chanali & & 490 \\
\hline Summa sumarum ut supra & ducati & 57585 \\
\hline Dazio de li uini dale isole zupana isola di mezo et calamota & & $240^{71}$ \\
\hline
\end{tabular}

[f. $4 \mathrm{v}]$

Qui pono tuta la intrata di stagno et ponta

\begin{tabular}{|l|r|r|}
\hline Dazio de la becharia di stagno et ponta & ducati & 230 \\
\hline Dazio di trageti atorno di stagno & & 20 \\
\hline Dazio di pasci di stagno & & 30 \\
\hline
\end{tabular}

70 Izvor je prepisan doslovno jer i njegov izričaj može poslužiti kao element za rješavanje pitanja autorstva i datacije.

$71 \quad$ Naknadno dopisana stavka. 


\begin{tabular}{|c|c|}
\hline Dazio deli uini di stagno et ponta & $1050^{72}$ \\
\hline Pastura di bestiami di stagno et ponta & 70 \\
\hline Molini tre di stagno & 30 \\
\hline Summa in le VI partite ut supra & 1430 \\
\hline $\begin{array}{l}\text { Sale si fa a stagno circha mogi grosi } 53000^{\wedge} \text { piu amancho sec- } \\
\text { ondo lanata di } 6 \text { per cento^ }{ }^{\wedge} \text { et lo creso di } 6 \text { per cento monta }\end{array}$ & 15900 \\
\hline
\end{tabular}

Qui pono la intrata di chanali

\begin{tabular}{|c|c|c|}
\hline Dazio deli uini in chanali & ducati & 360 \\
\hline Dazio di becharia di chanali & & 80 \\
\hline Molini XIIII di chanali & & 150 \\
\hline Summa in III partite ut supra & & 490 \\
\hline $\begin{array}{l}\text { Qui pono a summa tuta la intrata di ragusi con tuto lo contato } \\
\text { in tuto }\end{array}$ & & $57585^{73}$ \\
\hline $\begin{array}{l}\text { Qui pono a summo tuta la inscita de ragusa con tuto lo contato } \\
\text { in tuto e forastieri }\end{array}$ & & $46764^{74}$ \\
\hline $\begin{array}{l}\text { Resta neto trate le spese tuto quelo ochore in tute le chose alo } \\
\text { anno }\end{array}$ & & 18363 \\
\hline et a piu e man allzo $(?)^{75}$ ducati 1080 per le spese in forestieri & & $10821^{76}$ \\
\hline Item si guadagna delo giumrucho circha & & $2000^{77}$ \\
\hline
\end{tabular}

[f. 5 r]

Qui pono tuta la inscita dela ilustre cita de ragusa tuto per ordine alo anno per ordine

\begin{tabular}{|c|c|c|}
\hline Per data de rector & ducati & $1500^{78}$ \\
\hline Alli regitori et offiziali dentro in la cita & & 850 \\
\hline Alli comiti offiziali et chapitanei di fora & & 2900 \\
\hline Provisioni di panni si fano a ragusa & & 300 \\
\hline Alli salariati et changilieri a ragusa & & 1150 \\
\hline Provisioni ali medici et maistri di schola & & 2000 \\
\hline Alli soldati novi & & 4000 \\
\hline
\end{tabular}

72 Broj naknadno mijenjan. Izgleda kao da je isprva bilo upisano 1450, pa mijenjano u 1050, ili obratno.

73 Čini se da je prethodno pogrešno pisalo 57905 i 57985.

74 Ispravljani iznos.

75 Možda nejasno zapisano "mancho", kao gore.

76 Naknadno dopisana stavka.

77 Naknadno dopisana stavka.

78 Naknadno dopisana stavka. 


\begin{tabular}{|c|c|}
\hline Alli soldati vechi ungari & 600 \\
\hline Alli guardiani di muri per note & 370 \\
\hline Alla corte delo signor rectore di ragusa & 1300 \\
\hline Alli bombardieri XX de ragusa & $840^{79}$ \\
\hline Spese di lavorieri intra la cita & 500 \\
\hline Summa in XI partite & 15480 \\
\hline
\end{tabular}

Qui pono tuta la inscita di stagno

\begin{tabular}{|c|c|c|}
\hline Alli lavorenti dele saline a stagno & ducati & 900 \\
\hline Alli soldati et ongari & & 1200 \\
\hline Alli guardiani di note per li muri a stagno & & 220 \\
\hline Alli soldati di chasteli et corona & & 450 \\
\hline Summa in IIII parti ut supra & & 2870 \\
\hline
\end{tabular}

Qui pono l'inscita dela contra di chanali

\begin{tabular}{|l|r|r|}
\hline Alli dua vicicomiti in chanali & ducati & 90 \\
\hline Alli XV soldati di castel di sochol in chanali & & 340 \\
\hline Summa in II partite ut supra & & \\
\hline & & 430 \\
\hline Summa sumarum ut supra & & \\
& & 18330 \\
& & o val \\
& & $18330^{80}$ \\
\hline
\end{tabular}

[f. $5 \mathrm{v}$ ]

Inscite alli diversi principi del mondo

\begin{tabular}{|c|c|c|}
\hline Tributo alo glorioso re de ungaria & ducati & 500 \\
\hline Spese strasordenarie in forestieri & & 1500 \\
\hline Summa in II partite ut supra & & 2000 \\
\hline Tributo allo imperator di turchi & & 12500 \\
\hline Da sale la mita si vende con creso di 6 per cento li vene & & 9900 \\
\hline per la schala di narente de mogi grosi numero 12000 & & 10400 \\
\hline $\begin{array}{l}\text { Da salle la mita si vende a slano di mogi grosi numero } 4000 \\
\text { con creso di } 6 \text { per cento li vene }\end{array}$ & & $636^{81}$ \\
\hline
\end{tabular}

79 Naknadno je mijenjan broj bombardijera i trošak za njih.

80 Zbog ispravka prvotno upisanog zbroja 18680, koji je zamrljan, svota je dopisana još jednom.

81 Prekrižen je prethodno zapisan broj 398. 


\begin{tabular}{|c|c|}
\hline $\begin{array}{l}\text { Da salle la mita si vende a ploze for di ragusi di mogi grosi } \\
\text { numero } 20000 \text { con creso di } 6 \text { per cento li vene }\end{array}$ & 3180 \\
\hline $\begin{array}{l}\text { De salle la mita si vende a chastel novo de mogi grosi numero } \\
2000 \text { con creso di } 6 \text { per cento li vene }\end{array}$ & 318 \\
\hline Spese strasordenarie in turchi & 3000 \\
\hline Summa in VI partite ut supra & 21542 \\
\hline Summa summarum in tute inscite & $39222^{82}$ \\
\hline Spese in doni et altra trassordenari ali sangiachi & 1500 \\
\hline Spese strasordenarie che vene li turchi a raguxi & 2000 \\
\hline $\begin{array}{l}\text { Spese vano in corte del turcho con lo tributo si dano ali con- } \\
\text { seglieri et cortigiani al ano }\end{array}$ & 3000 \\
\hline Suma in 8 parte & 26334 \\
\hline & 17330 \\
\hline Suma sumarum per tuta la inscita & 46764 \\
\hline
\end{tabular}

82 Nastavak zapisa dodan naknadno. 


\section{Neobjavljeni izvori}

Hrvatska - Državni arhiv u Dubrovniku, ser. 6 - Detta, sv. 2

Hrvatska - Državni arhiv u Dubrovniku - DADU, ser. 18 - Officiales rationum, vol. 1 Istruzioni per l'Uffizio delle Cinque Ragioni

Hrvatska - Državni arhiv u Dubrovniku - DADU, ser. 19 - Privata

Hrvatska - Državni arhiv u Dubrovniku - DADU, ser. 21.1 - Manuali pratici del Canceliere. Leggi e istruzioni, sv. 2 - Specchio del Maggior Consiglio dell'anno 1500

Hrvatska - Državni arhiv u Dubrovniku - DADU, ser. 49 - Tesorieri Bilancia 1610-1619, sv. 1

Hrvatska - Državni arhiv u Dubrovniku - DADU, ser. 59 - Cassa communis, sv. 1

Hrvatska - Državni arhiv u Dubrovniku - HR-DADU, ser. 76 - Miscellanea saeculi XVI, kutija 9, sv. 3/1

Hrvatska - Nacionalna i sveučilišna knjižnica u Zagrebu - Zbirka rukopisa i starih knjiga (HR-NSK, Zbirka rukopisa i starih knjiga).

\section{Objavljeni izvori i literatura}

Batušić, Nikola; Fališevac, Dunja, ur. Zbornik Nikše Ranjine. O 500. obljetnici (1507. 2007.). Zagreb: HAZU, 2009.

Crijević, Ilija (Aelius Lampridius Cervinus, 1434 - 1520). De Epidauro et Ad Sanctum Blasium pro Rhacusa (1505), versio electronica (Ex libris). Prir. Darko Novaković. Croatiae auctores Latini. Pristup ostvaren 17. 4. 2020. http://www.ffzg.unizg.hr/klafil/croala/cgibin/getobject.pl?c.35:1:3.laud.

Di Vittorio, Antonio. Finanze e moneta a Ragusa nell'età delle crisi. Napoli: Giannini, 1983.

Dinić, Mihailo. „Jedna dubrovačka arhivska knjiga petnaestog veka”. Istorijski časopis 12-13 (1961-1962): 15-29.

Diversis, Filip de. Opis slavnoga grada Dubrovnika. Predgovor, transkripcija i prijevod s latinskoga Zdenka Janeković Römer. Zagreb: Dom i svijet, 2004.

Dokoza, Serđo. Dinamika otočnog prostora. Društvena i gospodarska povijest Korčule u razvijenom srednjem vijeku. Split: Književni krug Split, 2009.

Dokoza, Serđo. „Računski spisi srednjovjekovne korčulanske komune”. Povijesni prilozi 20 (2001), 20: 143-170.

Doumerc, Bernard. „Il dominio del mare”. U: Storia di Venezia. Dalle origini alla caduta della Serenissima, IV: Il Rinascimento. Politica e cultura, uredili Alberto Tenenti i Ugo Tucci. Roma: Enciclopedia Italiana, 1996. Pristup ostvaren 8. 4. 2020. http://www.treccani.it/enciclopedia/il-rinascimento-politica-e-cultura-tra-pace-e-guerra-le-forme-delpotere-il-dominio-del-mare_\%28Storia-di-Venezia\%29/.

Foretić, Vinko. Povijest Dubrovnika do 1808., knjiga 2. Zagreb: Nakladni zavod Matice hrvatske, 1980. 
Gaj, Velimir. Knjižnica Gajeva. Ogled bibliografskih studija. Zagreb: Tisak Narodne tiskare Gajeve, 1875.

Galić, Pavao. Povijest zadarskih knjižnica. Zagreb: Društvo bibliotekara Hrvatske, 1969.

Gelcich, Giuseppe. „Prefazione”. U: Serafino Razzi, La Storia di Ragusa, priredio Giuseppe Gelcich, III-LII. Ragusa: Editrice Tipografia Serbo-Ragusea A. Pasarić, 1903.

Goldthwaite, Richard A. The Economy of Renaissance Florence. Baltimore: The Johns Hopkins University Press, 2009.

Jagić, Vatroslav. „Uvod”. U: Pjesme Šiška Menčetića Vlahovića i Gjore Držića, priredio Vatroslav Jagić, I-XVI. Zagreb: JAZU, 1870.

Jurić, Šime. Katalog rukopisa Nacionalne i sveučilišne biblioteke u Zagrebu, svezak I. Zagreb: Nacionalna i sveučilišna biblioteka, 1991.

Notata diversa historiam civitatis Ragusinae illustrantia - http://skupnikatalog.nsk.hr/ Record/nsk.NSK01000676961/TOC\#toc

Kapetanić, Niko. Sokol grad u Konavlima. Dubrovnik: Vlastita naklada, 2013.

Kostić, Veselin. Dubrovnik i Engleska 1300-1650. Beograd: SANU, 1975.

Kralj-Brassard, Rina. „Detta presvijetlog i preuzvišenog gospodina kneza: troškovi Dvora u Dubrovniku od 16. do 19. stoljeća”. Anali Zavoda za povijesne znanosti HAZU u Dubrovniku 52/1 (2014): 131-160.

Liber viridis. Prir. Branislav Nedeljković, Beograd: SANU, 1984.

Luccari, Giacomo di Pietro. Copioso ristretto de gli annali di Rausa. In Venetia: Antonio Leonardi, 1605.

Macan, Trpimir. „Dubrovački barabanti u XVI stoljeću”. Anali Historijskog instituta JAZU u Dubrovniku 8-9 (1960-1961): 301-323.

Madunić, Domagoj. „The Defensive System of the Ragusan Republic (c. 1580-1620)”. U: The European Tributary States of the Ottoman Empire in the Sixteenth and Seventeenth Centuries, uredili Gábor Kármán i Lovro Kunčević, 341-372. Leiden: Brill Publishing, 2013.

Miović, Vesna. Dubrovačka diplomacija u Istambulu. Zagreb; Dubrovnik: Zavod za povijesne znanosti HAZU u Dubrovniku, 2003.

Nodilo, Speratus [Natko]. [„Uvod”]. U: Annales Ragusini anonymi item Nicolai de Ragnina, priredio Speratus Nodilo, V-XII. Zagreb: JAZU, 1883.

Novak, Grga. Povijest Splita, knjiga I: Od prethistorijskih vremena do definitivnog gubitka pune autonomije 1420. god. Split: Matica hrvatska, Pododbor, 1957.

Raukar, Tomislav. „Prilog poznavanju sistema prihoda dalmatinskih gradova u XIV. stoljeću”. Historijski zbornik 21-22 (1968-1969): 343-370.

Raukar, Tomislav. Srednjovjekovne ekonomije i hrvatska društva. Zagreb: Filozofski fakultet Sveučilišta u Zagrebu, 2003.

Razzi, Serafino. La Storia di Raugia. Lucca: per Venantio Busdraghi, [1595].

Razzi, Serafino. Povijest Dubrovnika. Preveli Iva Grgić, Stjepan Krasić i Anamarija Paljetak. Dubrovnik: Matica hrvatska, Ogranak Dubrovnik, 2011. 
Rešetar, Milan. „Uvod”. U: Pjesme Šiška Menčetića i Gjore Držića i ostale pjesme Ranjinina zbornika, priredio Milan Rešetar, 2. izdanje, IX-CXXXI. Zagreb: JAZU, 1937.

Rešetar, Milan. „Uvod”. U: Zadarski i Ranjinin lekcionar, priredio Milan Rešetar, V-XVI. Zagreb: JAZU, 1894.

Zadarski i Ranjinin lekcionar. Prir. Milan Rešetar. Zagreb: JAZU, 1894.

Statut grada Dubrovnika. Priredili i preveli Ante Šoljić, Zdravko Šundrica i Ivo Veselić. Dubrovnik: Državni arhiv u Dubrovniku, 2002.

Stojanović, Vedran; Lonza, Nella. „Krsna kumstva u Dubrovniku 18. stoljeća: djeca, roditelji i kumovi kao čvorovi društvenih mreža”. Anali Zavoda za povijesne znanosti HAZU u Dubrovniku 54/2 (2016): 339-371.

Šundrica, Zdravko. „Kako su stari Dubrovčani rješavali financijske krize”. U: Zdravko Šundrica, Tajna kutija Dubrovačkog arhiva, II, 329-332. Zagreb; Dubrovnik: Zavod za povijesne znanosti HAZU u Dubrovniku, 2009.

Vekarić, Nenad. Vlastela grada Dubrovnika, svezak 6: Odabrane biografije (Pi - Z). Zagreb; Dubrovnik: Zavod za povijesne znanosti HAZU u Dubrovniku, 2015.

Voje, Ignacij. „Poskusi kvantifikacije trgovskega prometa in proizvodnje v srednjeveškem Dubrovniku”. Zgodovinski časopis 42 (1988), br. 3: 373-387. 
Rina Kralj-Brassard*

Nella Lonza**

\section{Nikša Ragnina's Manuscript as a Source of Information on the Budget of the Dubrovnik Republic in the $16^{\text {th }}$ century}

\section{Summary}

The paper analyses the content and determines the dating and authorship of the manuscript R 3464 from the Collection of Manuscripts and Old Books at the National and University Library in Zagreb. Based on the data concerning the type and amount of state revenues and expenditures of the Dubrovnik Republic recorded in this manuscript, the period to which the budget refers has been determined. The credibility of the manuscript structure has been verified by comparison with the historically closest reliable data on government revenues and expenditures from the early 17 th century. The budget surplus shows the good state of public finances in the Dubrovnik Republic during the first quarter of the 16th century, while the structure of state revenues confirms the exceptional economic position of Dubrovnik. Although marked by multiple calculation errors, which indicate an unusual negligence towards numerical records, Ragnina's review of the budget, which is here transcribed in the appendix, is a valuable testimony to the economy of the Dubrovnik Republic in the early 16th century. Keywords: Nikša Ragnina, Dubrovnik, 16th century, state budget, surplus

\footnotetext{
* Rina Kralj-Brassard, Institute for Historical Sciences of CASA in Dubrovnik, Lapadska obala 4, 20000 Dubrovnik, Croatia, E-mail: rinafran@gmail.com

** Nella Lonza, Institute for Historical Sciences of CASA in Dubrovnik, Lapadska obala 4, 20000 Dubrovnik, Croatia,E-mail: nella.lonza@gmail.com
} 